\title{
Pomiędzy państwem prawnym a autorytaryzmem. Z polskich rozważań nad poszukiwaniem optymalnego ustroju państwa po odzyskaniu niepodległości w III Rzeczypospolitej
}

Konstrukcja państwa prawnego (der Rechtsstaat) jest uznawana za najdoskonalszą formę ustroju państwa nowożytnego. Polska, niosąca na tle tworzenia takiego systemu doświadczenia kilku istotnych porządków prawnych, ale też — co naturalne - oryginalne rozwiązania własnego ustroju, jest państwem unikalnym. Co paradoksalne, wiele instytucji publicznych do dziś w naszym kraju się jednak nie wykształciło, choć co do zasady konstrukcja państwa prawnego nie jest poddawana w wątpliwość. Niestety bolączki i niedojrzałości demokracji, które przeżywamy po 1918 r., sytuują polskie dyskusje o kształcie ustroju pomiędzy państwem prawnym a koncepcjami autorytaryzmu; jednocześnie żadna z nich nie stanowi najgłębszych interpretacji, pomimo faktu, że koncepcje autorytarne wydają się mniej dojrzałe.

W czasach zaborów próżno szukać na ziemiach polskich dominacji myśli autorytarnej ${ }^{1}$. Działo się tak nie tylko pomimo faktu, że nazwa taka jeszcze w tym czasie nie istniała, a w wielu państwach europejskich funkcjonowała (podobna w pewnych kwestiach do wykształconego później autorytaryzmu) monarchia konstytucyjna. Tradycja demokracji była, jak się wydaje, bardziej zakorzeniona w polskiej tradycji politycznej, a też od czasu jej powstania na ziemiach polskich była szeroko znana konstrukcja państwa prawnego. W zaborze rosyjskim, a na pewno w jego części zwanej Królestwem Kongresowym, za absolutnie pierwszoplanową książkę uznawano Encyklopedię umiejętności politycznych Roberta von Mohla (1799-1875), twórcy koncepcji państwa prawnego, w której powtórzył

1 Zob. np. A. Skwarczyński, Od demokratyzmu do autorytaryzmu, Warszawa 1998. 
on stworzoną przez siebie w wydanym wcześniej dziele wskazaną konstrukcję ustrojową ${ }^{2}$.

Z dzisiejszej perspektywy Robert von Mohl przedstawił bardzo dojrzałą koncepcję ustroju parlamentarnego. Pisał bowiem, że:

z przykrych doświadczeń wynika, że ludzie nie chcą być zdani wyłącznie na rozsądek i dobrą wolę książąt oraz ich pomocników i z tej racji nawet najbardziej uroczystych sformułowań wolnościowych praw jednostek oraz ustaleń dotyczących postępowania urzędników zawartych w konstytucji nie traktują jako dostatecznego zabezpieczenia. Przecież wiadomo, że nawet tego typu przepisy mogą być naruszane. Nawet zastosowanie najbardziej skrajnego środka przeciwko bezprawnej przemocy, mianowicie oporu, byłoby zarówno niepewne, jak i szkodliwe dla państwa. Na tym tle zrodziła się myśl, by dla ochrony praw obywateli powołać instytucję składającą się z nich samych oraz wyposażyć ją w niezbędne środki, konieczne do unormowanego i zgodnego z prawem wykonywania jej zadań3

Instytucją taką był właśnie parlament ${ }^{4}$. Jak więc wskazano, koncepcja parlamentaryzmu była dominująca w polskiej myśli publicznej doby zaborów, od czasu powstania partii, czy innych ugrupowań politycznych ${ }^{5}$. Po odzyskaniu niepodległości znalazła wyraz w konstytucji $1921 \mathrm{r}^{6}$ Choć Konstytucja marcowa $^{7}$ nie operuje pojęciem państwa prawnego, to jednak projektowany w niej ustrój odnosił się właśnie do takiej koncepcji. Ustroju tego nie naruszała istniejąca formalnie do 1922 r. instytucja Naczelnika Państwa ${ }^{8}$, w której Józef Piłsudski

${ }^{2}$ Zob. A. Bosiacki, Wstęp, [w:] R. von Mohl, Encyklopedia umiejętności politycznych, przeł. A. Białecki, wyd. II, Warszawa 2003, s. XLVI-XLVII. Za pierwszą książkę, w której przedstawiona została koncepcja państwa prawnego, uznawana jest Nauka policji zgodnie z zasadami państwa prawnego (R. von Mohl, Die Polizeiwissenschaft nach den Grundlagen des Rechtsstaates, t. I, Tübingen 1832, t. II: 1834, t. III: 1866), chociaż sam termin występował u innych autorów już wcześniej (por. np. A. Bosiacki, op. cit.).

3 R. von Mohl, System parlamentarny, [w:] B. Sobolewska, M. Sobolewski, Myśl polityczna XIX i XX wieku. Liberalizm, Warszawa 1978, s. 467; A. Bosiacki, op. cit., s. XVIII-XIX. Cytowany fragment pochodzi z książki R. von Mohla, Die Geschichte und Literatur des Staatswissenschaften (t. I-III, Tübingen 1855-1858).

${ }^{4}$ A. Bosiacki, op. cit., s. XVIII-XIX.

5 Wyjątek stanowiły w tym wypadku szeroko znane tzw. stronnictwa skrajne, do których jeszcze przed odzyskaniem niepodległości zaliczano radykalnych socjalistów i narodową demokrację (wtedy pod nazwą Ligi Narodowej); Scriptor (Erazm Piltz), Nasze stronnictwa skrajne, Kraków 1903.

6 Dz.U. $1921 \mathrm{Nr}$ 44, poz. 267 z późn. zm.

${ }^{7}$ Konstytucja 1921 r. była jednak oceniana przez współczesnych (także w nauce) bardzo krytycznie (z ostatnich prac zob. I. Lewandowska-Malec, Demokracje polskie. Tradycje - wspótczesność - oczekiwania, Kraków 2013, s. 144), nawiasem mówiąc, pomimo zgodności z dominującą wcześniej koncepcją parlamentaryzmu (co wynikało nie tyle z regulacji konstytucyjnych, lecz jak się wydaje - z niektórych aspektów polskiej specyfiki funkcjonowania parlamentaryzmu).

${ }^{8}$ A. Bosiacki, Ewolucja myśli polityczno-państwowej Józefa Piłsudskiego oraz jej wpływ na myśl społeczna i dokonania Drugiej Rzeczypospolitej, „Studia nad Autorytaryzmem i Totalitaryzmem” 37, 2015, nr 2, „Acta Universitatis Wratislaviensis” 3687, s. 7-27. 
harmonijnie funkcjonował $\mathrm{w}$ ramach — fakt, że coraz mniej stabilnej — demokracji parlamentarnej9.

Zarówno w trakcie, jak i po zakończeniu walk o granice państwa Piłsudski bez sprzeciwu podporządkowywał się parlamentarnej większości. Do wygaśnięcia urzędu Naczelnika Państwa współpraca Piłsudskiego z parlamentem układała się zatem w zasadzie bez zarzutu. Nie należy oczywiście w tym kontekście mylić współpracy z podstawową instytucją nowożytnego systemu przedstawicielskiego z niechęcią obozu narodowej demokracji czy poszczególnych posłów wobec osoby Piłsudskiego ${ }^{10}$. W żadnym wypadku nie można mówić o nadużywaniu władzy przez Piłsudskiego w tym okresie. Jest to tym bardziej godne podkreślenia, gdy weźmie się pod uwagę, że prerogatywy Naczelnika Państwa, nawet po ich ograniczeniu przez tzw. Małą Konstytucję, były naprawdę bardzo znaczące. W sensie formalnym Piłsudski nie dysponował takim zakresem władzy nawet po tzw. zamachu majowym.

W ciągu czterech lat pozostawania na stanowisku Naczelnika Państwa Sejm Ustawodawczy Rzeczypospolitej zatwierdził Piłsudskiego na tym stanowisku uchwałą z 20 lutego 1919 r. ${ }^{11}$ — była to właśnie tzw. Mała Konstytucja (wcześniej Piłsudski sprawował urząd tymczasowo). Akt ten stanowił, że Naczelnik Państwa jest najwyższym wykonawcą uchwał Sejmu w sprawach cywilnych i wojskowych. Powoływał także rząd, chociaż w rządzeniu faktycznie nie uczestniczył. Powoływanie Rady Ministrów musiało bowiem nie tylko nastąpić w porozumieniu z Sejmem, ale do zatwierdzenia każdego aktu normatywnego Naczelnika Państwa potrzebna była też zgoda właściwego ministra. Naczelnik Państwa, podobnie jak rząd, był ponadto odpowiedzialny przed Sejmem za sprawowanie swojego urzędu. Ograniczenie kompetencji Naczelnika Państwa nie wiązało się jednak z jakimkolwiek zagrożeniem ze strony Piłsudskiego. Przeciwnie — jak podkreślono - Naczelnik Państwa nie nadużywał władzy ani nie dał do tego powodów.

Pierwsze lata niepodległości zdołały zatem w sensie ustrojowym stworzyć harmonijną współpracę Naczelnika Państwa z Sejmem i rządem. Władza Naczelnika Państwa przybrała niewątpliwie istotny charakter w warunkach niestabilności sytuacji międzynarodowej i braku istnienia instytucji prezydenta. W zaistniałej sytuacji organ o podobnych kompetencjach - także na kształt naczelnego wodza, względnie Moderatora Imperii, jak później dyskutowano — nie był wcale utopijną wizją w poszukiwaniu ustroju państwa i jego najważniejszych instytucji ani nie kłócił się z zasadą parlamentaryzmu, choć $\mathrm{w}$ dłuższej perspektywie

${ }^{9}$ Nieco inne zdanie w tym względzie por. w szczególności A. Garlicki, Józef Piłsudski 1867-1935, Kraków 2008.

10 Zob. ibidem, np. s. 319 i 366, a szerzej A. Bosiacki, Ewolucja myśli..., z którego to artykułu zostały zaczerpnięte następne fragmenty, dotyczące tzw. Małej Konstytucji i rzeczywistości polskiego systemu politycznego do $1939 \mathrm{r}$.

11 Dz.U. $1919 \mathrm{Nr}$ 19, poz. 226. 
pozostawała oczywiście kwestia wzajemnego oddziaływania parlamentu i podobnego organu. Jest zatem paradoksem, że konstytucja z 1921 r. nie zagospodarowała politycznie w żaden sposób osoby tak zasłużonej dla odzyskania i utrzymania niepodległości jak Józef Piłsudski. Było to spowodowane niechęcią polityczną do osoby marszałka, którego można było obdarować prestiżowym tytularnym stanowiskiem albo też - jako zwycięzcę pod Warszawą — np. stanowiskiem naczelnego wodza.

Na mocy konstytucji zniknął urząd Naczelnika Państwa, a wprowadzono jak wiadomo - ustrój stricte parlamentarno-gabinetowy. Było to zgodne z klasyczną ideą demokracji, choć w konstytucji brakowało często konkretnych rozwiązań, które w poszczególnych przepisach projektowano na przyszłość (de lege ferenda). Józef Piłsudski złożył urząd Naczelnika Państwa na ręce prezydenta RP Gabriela Narutowicza 14 grudnia 1922 r. i — jak wiadomo — nie kandydował na urząd prezydenta w $1922 \mathrm{r}$.

Przedstawiony opis wycinka rzeczywistości przed zamachem majowym wart jest wskazania z punktu widzenia wkomponowania bezdyskusyjnego autorytetu jednostki w system parlamentarny. Po 1922 r. okazało się to w Polsce już niemożliwe, a rzeczywistość polityczna wytworzyła trwałą dychotomię pomiędzy autorytaryzmem a demokracją parlamentarną, przechylając się — rzecz jasna na korzyść tej pierwszej.

O autorytaryzmie II Rzeczypospolitej napisano dotychczas wyjątkowo dużo. Warto więc tutaj jedynie zauważyć, ze lata międzywojnia obfitowały w próby poszukiwania optymalnego ustroju politycznego (dla wielu także ustroju idealnego); nie wytrzymują one jednak krytyki z punktu widzenia współczesności. W II RP autorytaryzm mógł istnieć — być może — w pełni, jednak do końca życia Józef Piłsudski nie zdecydował się na objęcie urzędu prezydenta (pierwszy raz — jak wiadomo - po propozycji Sejmu w końcu maja 1926 r.) ${ }^{12}$. Powodowało to intensyfikację działań w rzeczywistości politycznej poza normami prawnymi, w której marszałek nie tylko się znajdował, lecz także z której to rzeczywistości był najwyraźniej zadowolony.

Jak wielu autorytarystów, Józef Piłsudski nie sformułował nigdy w sposób wyczerpujący swojej doktryny politycznej. Czynili to natomiast liczni ideolodzy obozu sanacyjnego, a w sensie szerszym doktrynę autorytaryzmu uosabiali także działacze pozasanacyjni (np. narodowej demokracji na czele z Romanem Dmowskim). Nie stanowili oni jednak nie tylko jednolitego obozu politycznego, ale także ich koncepcje nie doczekały się realizacji ${ }^{13}$. Projektowali z kolei — jak była

12 Pismo do marszałka Sejmu, zawiadamiajace o nieprzyjęciu wyboru na [urzad] Prezydenta Rzeczypospolitej, [w:] J. Piłsudski, Pisma zbiorowe, t. 9, Warszawa 1938, s. 33-34.

13 Zob. np. W.T. Kulesza, Koncepcje ideowo-polityczne obozu rzadzacego w Polsce w latach 1926-1935, Wrocław 1985. 
mowa - już to optymalny, już to nawet idealny system polityczny, próby którego zawsze spełzły na niczym ${ }^{14}$.

Najpełniej zrealizowanym programem autorytaryzmu II Rzeczypospolitej są Tezy Konstytucyjne Marszatka Pitsudskiego ${ }^{15}$ — jeden z nielicznych tej rangi zbiorów wskazówek, spisanych na podstawie bezpośrednich wypowiedzi marszałka w gronie najbliższych współpracowników. Tezy te są szczególnym źródłem o tyle, że dotyczą zasadniczych poglądów Piłsudskiego na kształt państwa po ewolucji jego koncepcji politycznych, a zatem polskiego autorytaryzmu u władzy oraz w późniejszym działaniu. Faktycznymi autorami Tez konstytucyjnych byli Stanisław Car (1882-1938), Bohdan Podoski (1894-1986) i wytypowany przez Piłsudskiego na następcę Prezes Bezpartyjnego Bloku Współpracy z Rządem (BBWR) pułkownik Walery Sławek (1879-1938), przy współudziale trzech innych bliskich współpracowników Piłsudskiego. Tezy stały się oficjalnym projektem przyszłej konstytucji, przegłosowanym w wyniku pewnych forteli legislacyjnych w Sejmie, co zostało skrytykowane przez Piłsudskiego. Po aprobacie Senatu projekt z pewnymi modyfikacjami został uchwalony.

Punktem wyjścia polskiego autorytaryzmu w myśli Piłsudskiego na temat kształtu państwa miał być r e a l z m. Piasecki wskazywał, że założeń Piłsudskiego nie cechowało bowiem wywodzenie państwa z umowy społecznej, społeczeństwa obywatelskiego bądź wiecznego pokoju ${ }^{16}$. Państwo dla Piłsudskiego miało być państwem „s połecznej równowag i”, bez przewagi lewicy i prawicy, a co za tym idzie bez walk partyjnych. Wzmocnienie państwa i jego autorytetu było dla niego siłą władzy państwowej — nie mogła jej realizować władza parlamentu, w przeciwieństwie do prezydentury; Prezydent Rzeczypospolitej miał być wyłączony spod wpływów partii politycznych i Sejmu.

W zakresie rządzenia marszałek proponował z kolei „techniczną sprawność lecz także naczelnych władz państwowych". Rządzenie zarezerwowane było jednak nie tylko dla jednostek, lecz także zbiorowości. Piłsudski nie odrzucił również trójpodziału władzy, której organy określił jako „, tr zy głów ne sprężyny, poruszające maszyną państwa”. Było niestety jasne, że główną sprężyną władzy będzie instytucja prezydenta.

W zakresie formy państwa Piłsudski zadeklarował istnienie Sejmu i Senatu. Był jednak przeciwny parlamentaryzmowi jako formie rządów. Był natomiast

14 Próby stworzenia optymalnego, czy nawet idealnego systemu politycznego, zajęły wtedy umysły wielu prawników i teoretyków polityki wszystkich niemal kierunków politycznych. Rozważania na ten temat autor pragnąłby jednak przedstawić w przyszłości w odrębnej publikacji.

15 A. Piasecki, Tezy konstytucyjne Marszałka Pitsudskiego. Referat wygłoszony w dniu 28 lutego 1931 r. u Marszatka Senatu Władystawa Raczkiewicza. Drukowane jako rękopis [broszura], Warszawa 1931. Omówienie tez i ich implikacji, włącznie z zasadami konstytucji 1935 r., za: A. Bosiacki, Ewolucja myśli...

16 A. Piasecki, op. cit., s. 6. Opisując źródło państwa, autor nie używał tych pojęć, ograniczając się jedynie do wyszczególnienia ich twórców. Był to dość dziwny zabieg, mający ukryć terminy już wtedy szeroko dyskutowane. 
zwolennikiem jakiejś formy przedstawi cielstwa, co było zgodne z wieloma koncepcjami autorytaryzmu tamtych lat.

Podobnie jak podział władzy, konstytucja według Piłsudskiego miała przede wszystkim ściśle rozgraniczać k o mpeten cje między prezydentem, legislatywą i rządem. Nie miała też stanowić państwa rządzonego przez abstrakcyjne prawo - prawo miało stanowić ład i być maksymalnie ścisłe. W innym przypadku, jak miało to miejsce w 1921 r., konstytucja byłaby niechlujna, co powodowałoby problemy w obowiązywaniu aktów prawnych niższej rangi.

Centralne miejsce w doktrynie Piłsudskiego zajęła rzecz jasna koncepcja prezydenta. Prezydent RP miał być w niej najwyższym suwerenem państwa, regulatorem między władzami, sprawującym zwierzchnictwo ponad innymi władzami, mogącym rządzić bezpośrednio w sytuacjach nadzwyczajnych (lecz bez recepcji modelu amerykańskiego). Miał mieć w s p ółu dzi ał we władzy wykonawczej i sądowej, sprawowałby również dowództwo nad wojskiem. Odmiennie niż w konstrukcji Naczelnika Państwa, akty prezydenta nie wymagałyby kontrasygnaty poszczególnych ministrów. Piłsudski proponował natomiast — także przed Sejmem - konstytucyjną odpowiedzialność prezydenta. Nawet prezydent nie miałby jednak możności zmiany konstytucji, która byłaby aktem stałym, mogącym zostać zmienionym prawdopodobnie jedynie przez wszystkie trzy współpracujące w tej kwestii władze.

Trzeba podkreślić, że Piłsudski nigdy nie określił, że chciałby zostać P re zydentem Rzeczypospolitej. Aczkolwiek wydawało się to jasne. Jak była mowa, tak jak wielu autorytarystów, miał zwyczaj nie dopowiadać niektórych kwestii, udzielać nie do końca precyzyjnych wskazówek, a niektóre sprawy pozostawiać otwarte. Nie przyjął jednak urzędu prezydenta po zamachu majowym, stwierdzając, że funkcja nie ma wystarczających kompetencji. Doprowadził natomiast do powołania na stanowisko prezydenta człowieka bez większego znaczenia politycznego, aby sprawował najwyższy urząd w państwie formalnie pod rządami konstytucji, której nie aprobował. Wreszcie, przedstawił tezy prezydentury całkowicie odmiennej niż dotychczasowa, w której prezydent miałby np. dowodzić wojskiem. Z przedstawionych faktów najbliżsi współpracownicy marszałka wysnuli wniosek, że Piłsudski myślał również o sobie w kontekście przedstawionej koncepcji prezydentury.

Tak zwana Konstytucja kwietniow a jest postrzegana przede wszystkim przez pryzmat systemu prezydenckiego. Istotnie — jak była mowa — instytucja prezydenta zajęła w niej centralne miejsce. W konstytucji jest jednak sporo innych, wartych wskazania, konstrukcji, w tym pierwsze dziesięć artykułów określanych jako tzw. dekalog konstytucyjny ${ }^{17}$. I tak Rzeczypospolita została określona jako ws pólne dobro wszystkich obywateli (art. 1), ze stojącym na czele

${ }^{17} \mathrm{Z}$ tego m.in. względu tej konstytucji (podobnie jak innych konstytucji RP) nie można nazwać ustawą zasadniczą, określającą jedynie rozdział kompetencji najwyższych organów władzy publicznej w państwie. Oba terminy bywają często mylone. 
państwa prezydentem, sprawującym jednolitą i niepodzielną władzę państwową. Określono też, że państwo jest fundamentem życia społecznego, wolności osobiste nie mogą naruszać dobra powszechnego, a praca jest podstawą rozwoju i potęgi Rzeczypospolitej. Wbrew stosunkowo częstym tendencjom, konstytucja 1935 r. nie wprowadzała skrajnie niedemokratycznego modelu rządów. Niektóre instytucje, jak samorząd terytorialny czy wymiar sprawiedliwości, zachowały np. atrybuty niezależności. Konstytucja zdała również — jak wiadomo — swoisty egzamin w czasie wojny: była w stanie zapewnić ciągłość państwa i jego władzy zwierzchniej w osobie prezydenta. Inna rzecz, że po śmierci Piłsudskiego, która — jak była mowa - nastąpiła w krótkim czasie po uchwaleniu konstytucji, nikt z jego następców nie dysponował już autorytetem zarezerwowanym dla prezydenta w Konstytucji kwietniowej.

Piłsudczycy bez Piłsudskiego są bowiem pewną karykaturą dokonań, wizji i przede wszystkim właśnie autorytetu politycznego i społecznego marszałka. Jest to też cechą systemów autorytarnych, upadających po śmierci swego patrona, którego autorytet wypływa często bardziej z autentycznych pobudek niż powodów sztucznie kreowanych. Po śmierci Piłsudskiego w historii Polski miała miejsce taka właśnie sytuacja, a autorytaryzm w Polsce zaczął przybierać coraz bardziej karykaturalne formy.

Z punktu widzenia dokonań II I R zeczypospolitej (po 1989 r.) widać niestety pewne analogie w ewolucji systemu politycznego od demokracji do autorytaryzmu oraz brak stabilności i dojrzałości, by nie powiedzieć d e k o m p o zy cję systemu partyjnego. Wiąże się to z co najmniej kilkoma czynnikami, lecz przede wszystkim z rozczarowaniem nie tyle niedojrzałą formą demokracji po 1989 r., ile negacją jej poszczególnych aspektów (dotyczy to zarówno zmian politycznych, jak i gospodarczych).

Zjawiska takie określono szerzej mianem p o s t k o m u n i z m u ${ }^{18}$, który przy zanegowaniu deklarowanych szerokich, m.in. społecznych, obowiązków państwa w dawnym ustroju przy braku całościowych i spójnych przekształceń systemu doprowadził do wykluczenia i nawet pauperyzacji wcale niemałej części społeczeństwa, a w sensie politycznym do wytworzenia niestabilnego systemu, także partyjnego. Prawie 30 lat reform politycznych w Polsce nie doprowadziło w szczególności właśnie do wykształcenia dojrzałego systemu partii politycznych. W państwach postkomunistycznych po 1989 r. następowała z początku pewna krystalizacja kierunków politycznych, która jednak do dnia dzisiejszego nie tylko nie została zakończona, ale wręcz wykazuje cechy uwstecznienia. Polska jest w tym wypadku jednym z krajów postkomunistycznych, w którym krystalizacja kierunków politycznych nie nastąpiła ${ }^{19}$. Brak ukształtowania sceny

18 J. Staniszkis, Postkomunizm: próba opisu, Gdańsk 2001; J. Winiecki, „Transformacja postkomunistyczna". Studium przypadku zmian instytucjonalnych, Warszawa 2012.

19 Ostatnie dwa zdania cyt. za: A. Bosiacki, Kierunki nowożytnej myśli politycznej w programach polskich ruchów politycznych lat 1989-2006, [w:] Ideowość w polityce, red. M. Szyszkowska, 
politycznej został w tym przypadku zastąpiony w wielu kwestiach dyskursem publicznym ${ }^{20}$. Podobne zjawiska cechuje zresztą współczesna polityczna rzeczywistość z koncepcjami postmodernizmu (ponowoczesności), postpolityki czy postprawdy na czele.

O ile system partyjny III Rzeczypospolitej należy ocenić zdecydowanie negatywnie, istotnym osiągnięciem transformacji jest konstytucja przyjęta — jak wiadomo - osiem lat po upadku komunizmu. Jej wartością jest w szczególności katalog aksjologiczny oraz wypracowanie pozycji Prezydenta Rzeczypospolitej przy całkowitym zachowaniu systemu parlamentarno-gabinetowego. Jest to kompromis między doświadczeniami konstytucji 1921 i 1935 r. (zdecydowanie na korzyść tej pierwszej), stanowiący — rzecz jasna — wyraz koncepcji nieautorytarnej.

W myśl wskazanej konstrukcji i przepisów konstytucji głowa państwa znajduje się poza ściśle bieżącymi stosunkami politycznymi. W żadnym też razie uprawnienia prezydenta nie wykraczają poza normy prawne, co jest zjawiskiem typowym dla autorytaryzmu. Autorytet prezydenta jest ponadto zapewniony przez konstytucję.

$\mathrm{W}$ polskim systemie parlamentarnym brak jest obecnie partii politycznej, deklarującej zasady autorytarne czy też np. zasadę wodzostwa ${ }^{21}$. Mimo poszukiwania optymalnej wizji ustroju (przede wszystkim gospodarczego i społecznego) i — jak będzie mowa - dużej niedojrzałości polskiego systemu partyjnego, jest to bardziej poszukiwanie jakiejś — być może — formy funkcjonowania państwa prawnego niż autorytaryzmu. Co pewien czas pobrzmiewa projekt zmiany konstytucji (partie PiS, Kukiz '15) na korzyść uprawnień prezydenta (wobec nie tylko władzy wykonawczej, lecz także sądowniczej) ${ }^{22}$ czy instytucji

Warszawa 2007, s. 112. Większość fragmentów analizy rzeczywistości politycznej III Rzeczypospolitej pochodzi z tego opracowania (ibidem, s. 112-128).

20 W. Szewczak, Dyskurs publiczny jako substytut reprezentacji politycznej-wymiar parainstytucjonalny współczesnej demokracji, http://www.academia.edu/5531857/Dyskurs_publiczny_jako_ substytut_reprezentacji_politycznej_wymiar_parainstytucjonalny_wsp $\% \mathrm{C} 3 \% \mathrm{~B} 3 \% \mathrm{C} 5 \% 82 \mathrm{czesnej}$ demokracji (dostęp: 5.04.2017).

21 Pewnym wyłomem są w tym wypadku wchodzące czasem do parlamentu radykalne partie polityczne, odwołujące się np. do ideologii narodowej demokracji. W praktyce politycznej III Rzeczypospolitej miało to jednak miejsce najczęściej pod nazwami czy kierunkami politycznymi takich partii (np. Wyborcza Akcja Katolicka, Liga Polskich Rodzin, czy częściowo Stowarzyszenie Kukiz '15).

${ }^{22}$ W programie PiS z 2014 r. czytamy np.: „że w warunkach umożliwiających nowelizację Konstytucji rozwiązaniem optymalnym będzie wyprowadzenie organu orzekającego w sprawach odpowiedzialności dyscyplinarnej poza korporację sędziowską i usytuowanie go przy organie powołującym sędziów, czyli Prezydencie Rzeczypospolitej, z możliwością odwołania się od orzeczenia dyscyplinarnego do Sądu Najwyższego. Rola Prezydenta Rzeczpospolitej w sprawach sądownictwa nie może być redukowana do funkcji „,notariusza” sporządzającego akty nominacji sędziowskich. Głowa państwa powinna uzyskać ograniczony, ale realny wpływ na funkcjonowanie sądownictwa. Oprócz powoływania członków organu orzekającego w sprawach odpowiedzialności 
referendum; ostatni projekt z 2010 r. został jednak przez obecną partię rządzącą usunięty ${ }^{23}$, co może świadczyć o wycofaniu się z koncepcji mocno krytykowanej przez medialną opozycję. Krytycy zarzucali projektowi, że de facto prowadziłby w Polsce do systemu autorytarnego. Zakładał w szczególności możliwość skrócenia przez prezydenta kadencji Sejmu, co jako instytucję zniesiono w konstytucji z $1997 \mathrm{r}^{24}$, a co istnieje w niektórych państwach postkomunistycznych (w szczególności w Rosji). Była to instytucja potencjalnie niebezpieczna dla polskiego systemu politycznego. W obecnej chwili nie można jednak stwierdzić, że partia rządząca zaproponuje zbudowanie w Polsce systemu autorytarnego (podobnie nie wystarczą twierdzenia o konflikcie rządzącej partii politycznej i rządu z dawnym składem Trybunału Konstytucyjnego), choć dziwi projekt zmiany k onstytucji, mającej za podstawę wolę narodu, wyrażoną w referendum, zaplanowanym na $2018 \mathrm{r}^{25}$

Katalog aksjologiczny polskiej konstytucji ${ }^{26}$ zakłada umocowanie przede wszystkim w myśli liberalnej (zasada demokratycznego państwa prawnego, urzeczywistnianie zasad sprawiedliwości społecznej, zapewnianie wolności i praw człowieka i obywatela oraz bezpieczeństwo obywateli), ale też konserwatywnej (wyrażona w art. 1 zasada dobra wspólnego wszystkich obywateli, pojęcie dziedzictwa narodowego czy narodowej kultury jako źródła tożsamości

dyscyplinarnej sędziów Prezydent Rzeczypospolitej będzie sprawować, przy pomocy powołanej przez siebie komisji złożonej z wybitnych, cieszących się autorytetem prawników (np. przedstawicieli nauki prawa oraz sędziów Sądu Najwyższego, Naczelnego Sądu Administracyjnego i Trybunału Konstytucyjnego w stanie spoczynku), nadzór nad rozpatrywaniem skarg na sądy. Wspomniana Komisja będzie badać odwołania skarżących i sędziów od rozstrzygnięć wydawanych w pierwszej instancji przez Ministra Sprawiedliwości w wyniku skarg na sądy. Sprawując tego rodzaju nadzór, Prezydent Rzeczypospolitej uzyska szczegółową wiedzę o funkcjonowaniu wymiaru sprawiedliwości, bardzo przydatną przy podejmowaniu decyzji w sprawie nominacji sędziowskich" (Program PiS 2014, s. 67).

${ }^{23}$ PiS usunęło z sieci projekt swojej konstytucji. Co zawiera ten dokument, „Gazeta Prawna", 20.10.2015, http://www.gazetaprawna.pl/artykuly/900647,projekt-konstytucji-pis-wyboryparlamentarne-2015.html (dostęp: 28.04.2017). Zob. projekty konstytucji autorstwa PiS z 2010 r. i stowarzyszenia Kukiz '15 (brak możliwości oceny, czy zamieszczony projekt konstytucji Prawa i Sprawiedliwości został przez tę partię wycofany z obiegu społecznego).

${ }^{24}$ Skrócenie kadencji Sejmu i Senatu przewidywała m.in. Mała Konstytucja z 1992 r. oraz nowela sierpniowa z 1926 r. i Konstytucja kwietniowa. W nowej konstytucji rozwiązanie izb zniesiono.

25 W chwili pisania tekstu Prezydent RP zgłosił taki postulat (dokładnie 3 maja 2017 r. w przemówieniu w rocznicę uchwalenia tzw. Konstytucji 3 maja). Nie przesądzono jednak, czy referendum miałoby dotyczyć wyrażenia zdania na temat opracowanego projektu konstytucji, czy też jedynie wyrażenia aprobaty do podjęcia prac nad projektem nowej konstytucji, a następnie doprecyzowano, że w referendum miałoby paść kilkanaście pytań, m.in. o pozycję poszczególnych rodzajów władzy. Jak zwracali uwagę niektórzy konstytucjonaliści, jest to sprzeczne z obowiązującymi przepisami, zabraniającymi uchwalenia bądź zmiany konstytucji w drodze takiego referendum (art. 235 Konstytucji).

26 Zob. np. H. Izdebski, Doktryny polityczno-prawne. Fundamenty wspótczesnych państw, wyd. 3, Warszawa 2015. 
narodu polskiego, jego trwania i rozwoju, ochrona małżeństwa i rodziny, zasada państwa jednolitego) czy katolickiej (fakt, że konstytucja zawiera znaną formułę inwokacyjną, w katalogu wspólnych wszystkim obywatelom wartości konstytucyjnych odwołującą się do „wierzących w Boga, jak niepodzielających tej wiary" oraz zasada zrównoważonego rozwoju) i socjalnej (społeczna gospodarka rynkowa, opieka społeczna, wolność tworzenia związków zawodowych). W wielu wypadkach aksjologiczne zasady konstytucji dotyczą zresztą łącznie niejednego ze wskazanych kierunków. Zasadę państwa prawnego wyrażają w szczególności: zasada trójpodziału władzy i równowagi władz, przestrzeganie prawa międzynarodowego, wolność tworzenia i działania partii politycznych w celu wpływania metodami demokratycznymi na kształtowanie polityki państwa.

W systemie politycznym nie tylko współczesnej Polski dominuje wciąż słusznie najbardziej czytelny, tym bardziej w państwie kształtowanej demokracji, podział na lewicę i prawicę ${ }^{27}$. Od początku transformacji większość społeczeństwa polskiego deklaruje sympatię po stronie prawicy $(36,5 \%$ wobec $19,7 \%$ sympatyków lewicy $)^{28}$, jednak pojęcia takie dla wielu respondentów są w znacznym stopniu nieprecyzyjne. Widać to także w kontekście rozwoju w nowym systemie polskiego spectrum sceny politycznej.

Początki kształtowania się polskiego systemu politycznego po 1989 r. powodowały np. tworzenie ruchów kosztem partii politycznych sensu stricto. Pierwszym ruchem politycznym były tzw. komitety obywatelskie „Solidarność”, mające z założenia grupować różnorakie inicjatywy o znaczeniu lokalnym. Wysuwana przez przeciwników tej instytucji teza mówiła o wypełnianiu przez komitety obywatelskie władzy lokalnej po upadku systemu komunistycznego ${ }^{29}$, być może na kształt istniejących w PRL „rad narodowych”. W pierwszym okresie po tzw. Okrągłym Stole komitety obywatelskie istniały w środowiskach lokalnych zamiast partii politycznych. W sensie ideowym nie reprezentowały ani nie deklarowały żadnego konkretnego kierunku politycznego; cechowała je zatem be zideowość albo wieloideowość. Wskazywaną przez komitety ideowość reprezentował często - wkrótce potem krytykowany — tzw. etos Solidarności ${ }^{30}$, który nigdy nie został wyraźnie określony w sensie politycznym, a współcześnie w środowiskach, które uznawały etos taki za istotny po 1989 r., bywa wręcz

27 Por. np. T. Godlewski, Identyfikacje ideologiczne a preferencje wyborcze spoleczeństwa polskiego, „Historia i Polityka”, 2016, nr 15 (22), s. 9-19. Odmiennie: H. Izdebski, op. cit., s. 34-38.

28 T. Godlewski, op. cit., s. 11.

29 Por. np. J. Kurski, P. Semka, Lewy Czerwcowy, Warszawa 1992 (wywiad z Jarosławem Kaczyńskim), a ostatnio J. Kaczyński, Porozumienie przeciw monowładzy. Z dziejów PC, Warszawa 2016. Wskazani autorzy za dążenie do neomonolitu wskazywali oczywiście nie tylko komitety obywatelskie Solidarność, lecz także partię nazwaną wkrótce Unią Demokratyczną.

30 Por. np. E. Podgajna, Obchody 25-lecia Solidarności, „Gazeta Wyborcza”, 28.08.2005. 
uznawany w kategoriach społecznego czy socjalnego „mitu”. Według niniejszego podejścia mit taki może służyć jako instrument działania inżynierii społecznej ${ }^{31}$.

Ruchy polityczne z czasem zyskały na znaczeniu, negując na dodatek potrzebę istnienia partii politycznych. Do koncepcji takiej nawiązywały w różnym okresie III Rzeczypospolitej Platforma Obywatelska (na początku swego powstania deklarująca się jako nie-partia polityczna), Akcja Wyborcza Solidarność (będąca konglomeratem małych liczbowo deklarujących się jako prawicowe partii politycznych), a także quasi związek zawodowy Samoobrona RP. W Sejmie i Senacie obecnej kadencji tzw. partiokrację zwalcza usilnie ruch Kukiz '15, posiadający chyba najmniej skrystalizowaną nazwę ugrupowania politycznego po upadku komunizmu w Polsce (poza kuriozalną Polską Partią Przyjaciół Piwa z 1991 r. i analizowaną dalej .Nowoczesną bądź Nowoczesną Ryszarda Petru). Podobnie jak w wielu innych wypadkach, cechą Stowarzyszenia Kukiz '15 jest brak programu politycznego, zastępowany kilkoma postulatami politycznymi, jak np. jednomandatowe okręgi wyborcze, szerokie stosowanie instytucji referendum, powiększenie kwoty wolnej od podatku i likwidacja gabinetów politycznych ministrów oraz zwiększenie uprawnień prezydenta ${ }^{32}$.

Kolejną cechą polskiego systemu politycznego po 1989 r. zdaje się znacząca rola polityczna związków zaw odowych. W państwach tzw. rozwiniętej demokracji rola taka należy w najlepszym razie do przeszłości (por. przykład Wielkiej Brytanii) i często zdecydowanie wiąże się z populizmem (vide Argentyna za rządów Juan Domingo Peróna). W Polsce po 1989 r. wielokrotnie zwracano uwagę na niewyłącznie socjalny element działania związków zawodowych w polityce. Zjawisko takie związki zawodowe pojmowały znacznie bardziej w kontekście silnego państwa opiekuńczego niż jako zjawiska społecznego o bardziej perspektywicznym charakterze.

W sposób zdecydowany związki zawodowe w Polsce po 1989 r. wykazywały silną polityzację. Jak wiadomo, opowiadały się za konkretnymi ugrupowaniami politycznymi (kiedyś SLD albo AWS) i miały swoich przedstawicieli w parlamencie. Związek zawodowy tworzył także nominalnie ruch polityczny (Akcja Wyborcza Solidarność), przez cztery lata będąc de iure rządzącą p a r ti ą p oli ty czną (albo ruchem politycznym) ${ }^{33}$. Trzeba jednak nadmienić, że przykłady politycznej i dualistycznej roli Solidarności nie są typowe tylko dla tego związku zawodowego. Związek Nauczycielstwa Polskiego nominalnie wchodził w skład

31 Zob. W. Maciszewski, Bezpieczne zwiazki, „Gazeta Wyborcza”, 27.08.2005.

32 „Strategia zmiany” zakłada w tym przypadku obligatoryjność referendum (ruchkukiza.pl).

33 Nominalnie Akcja Wyborcza Solidarność na początku swego istnienia nie była partią, ale ruchem politycznym, w którym NSZZ „Solidarność” stanowiła siłę dominującą. Po powołaniu Ruchu Społecznego AWS, w skład którego wchodziło wielu członków partii, wchodzących wcześniej w skład AWS, klarowność partyjna ruchu uległa jednak osłabieniu. 
SLD, a polityczną rolę eksponował także Związek Zawodowy Samoobrona. Formalnie odrębnie od tego ostatniego funkcjonowała partia o takiej samej nazwie ${ }^{34}$. Jest to, raczej nieświadome, powtórzenie schematu jednoczesnego istnienia pod tym samym szyldem związku zawodowego i r u chu polity c zne go, funkcjonującego kiedyś pod nazwą „Solidarność”.

Mocno upolitycznione związki zawodowe w Polsce w sensie ideologicznym nie reprezentują żadnego kierunku politycznego. Odwołując się najczęściej do spraw społecznych, źródło swego programu wskazują czasami w społecznej nauce Kościoła rzymskokatolickiego. Stwierdzenia takie nie wychodzą jednak poza ramy deklaracji.

Kolejną cechą polskiego systemu politycznego są partie wieloideowe. Prezentują one niesprecyzowany, a czasami wielokierunkowy obraz ideologiczny. Po 1989 r. partie takie czasami wręcz odcinały bądź odcinają się od jednoznacznego kierunku politycznego.

Chronologicznie pierwszym przykładem partii politycznej o takim charakterze zdawała się Unia Demokratyczna (później Unia Wolności). Ugrupowanie to nigdy nie odwoływało się stricte do żadnego tradycyjnego kierunku politycznego, a należeli doń ludzie odwołujący się zarówno do chrześcijańskiej demokracji (np. Tadeusz Mazowiecki, Andrzej Wielowieyski), liberalizmu (np. Donald Tusk, Janusz Lewandowski), jak i postaw socjalistycznych (np. Jacek Kuroń i Jan Lityński). Według dostępnej wiedzy spośród tych kierunków wskazywano jednak tylko liberalizm, choć w ramach UD (UW) istniały niesprecyzowane niby-frakcje (np. frakcja społeczna czy frakcja liberalna) ${ }^{35}$. Podobną rolę na początku istnienia przyjęła również - jak wskazano początkowo - niedeklarująca się jako partia polityczna, Platforma Obywatelska.

O kierunku politycznym z reguły niewiele mówią także nazwy partii politycznych współczesnej Polski. Nazwy takie cechuje nie tylko nieostrość i niedookreślenie, lecz także — w ostatnich latach — stosunkowo częste ich zmiany. Na polskiej scenie politycznej co pewien czas pojawiają się ponadto bardzo dziwne semantycznie twory polityczne (,bloki”, „platformy”, ,akcje”, „centra”, na czele z przywołaną już istniejącą kiedyś Polską Partią Przyjaciół

34 Informacja ze strony www.samoobrona.pl. Mniej więcej od listopada 2006 r. Związek Zawodowy Samoobrona RP funkcjonował pod nazwą Związek Zawodowy Rolnictwa (ibidem).

35 Współcześnie znacznie klarowniejsza może wydawać się nazwa kontynuatorki Unii Wolności - Partii Demokratycznej. Jej nazwa sugerowałaby odniesienia do programu Partii Demokratycznej w Stanach Zjednoczonych, operującej hasłami liberalizmu socjalnego i szeroko pojętej światopoglądowej niekonserwatywnej wolności. Podobnie jak w wypadku innych partii politycznych (patrz dalej), program PD zawiera jednak w ogromnej większości zbiór bieżących wskazówek, pod którymi mogłoby podpisać się bardzo wiele środowisk politycznych od lewicy do prawicy (zob. program partii na stronie internetowej www.demokraci.pl). 
Piwa) ${ }^{36}$. Współczesny polski konstytucjonalista określił takie zjawisko jako jeden ze składników „kiczu w polityce" 37 .

Nazwy partii i ugrupowań politycznych współczesnej Polski ewoluują czasami również w kierunku pewnego rodzaju zamknięcia i swoiście pojmowanej integralności. Ewolucja nazw partii politycznych po 1989 r. w naszym kraju wykazuje w tym przypadku pewne „semantyczne uwstecznianie” na rzecz konfrontacyjności i radykalizmu oraz rozszerzanie zakresu desygnatów nazwy ${ }^{38}$.

Spośród partii politycznych uczestniczących w sprawowaniu władzy po 1989 r. najbardziej skrystalizowane wydają się takie kierunki jak socjaldemokracja i „endecja”. Program Socjaldemokracji Rzeczypospolitej Polskiej jest w takim zestawieniu wyrażony klarownie, w dodatku w sposób wyraźny deklarując odróżnienie tej partii od „prawicy, liberałów i populistów”39. Niesocjaldemokratyczne są w nim dość silne akcenty personalistyczne, ale i te można by wythumaczyć podobnymi zjawiskami występującymi w myśli lewicy francuskiej. Program SLD wskazuje natomiast tak typowe jej cechy, jak socjaldemokracja (demokracja

36 P. Winczorek, Kicz w polityce, [w:] idem, Polska pod rzadami Konstytucji z 1997 r., Warszawa 2006, s. 146.

37 Ibidem.

38 Por. np. nazwy Platforma Obywatelska (wcześniej np. Unia Wolności czy Kongres Liberalno-Demokratyczny, kojarzące się z liberalizmem), Prawo i Sprawiedliwość (wcześniej Porozumienie Centrum, uznające się za partię centroprawicową), dawna Liga Polskich Rodzin (powstała ze Stronnictwa Narodowego Stronnictwa Narodowo-Demokratycznego, Młodzieży Wszechpolskiej i Rodziny Warszawskiej, czyli organizacji kojarzących się — poza ostatnią — jednoznacznie z przedwojenną ,endecją”). Jak była mowa, nazwę partii politycznej na związek zawodowy (czy odwrotnie) dokonała także Samoobrona RP.

39 Pierwotnie: Projekt konstytucji programowej SLD, Warszawa 1999. Według programu: „dla SLD lewica oznacza realne dobro społeczne i realne dobro jednostki ponad wszelkie abstrakcyjne mechanizmy rynku i państwa. W konflikcie między kapitałem i pracą zawsze opowiadamy się po stronie pracy” - piszą autorzy programu. - „Dążymy do stworzenia oraz egzekwowania zasad i praktycznych możliwości godnego zatrudnienia i rozwoju każdego człowieka. Praca nie może upokarzać i musi być sprawiedliwie wynagradzana. Zarazem w konflikcie między konserwatywnymi regułami społecznymi a modernizacją stajemy po stronie uniwersalnych humanistycznych wartości. Chcemy stwarzać człowiekowi coraz szerszą przestrzeń do samorealizacji. Jedynym ograniczeniem tej zasady jest dobro wspólne. W konflikcie między autorytaryzmem a demokracją niezmiennie bronimy demokracji”. Ponadto: „szczególną wagę przywiązujemy do dorobku programowego partii socjaldemokratycznych Zachodu i przedwojennej Polskiej Partii Socjalistycznej. Z szacunkiem odnosimy się do dorobku twórców Polskiego Października '56, późniejszej lewicowej opozycji demokratycznej, reformatorskich nurtów Polskiej Zjednoczonej Partii Robotniczej, inicjatorów Okrągłego Stołu oraz do doświadczeń Socjaldemokracji Rzeczypospolitej Polskiej. A także rodzimego ruchu spółdzielczego, polskich sufrażystek, wolnomyślicieli. Nie odtrącamy żarliwości polskich komunistów, nie zgadzając się na totalitarny model państwa i społeczeństwa. Z tych samych powodów, doceniając i szanując modernizacyjne osiągnięcia Polski Ludowej, które były dziełem milionów uczciwych Polaków, potępiamy krzywdy, wyrządzone w imię cywilizacyjnych i socjalnych ideałów". 
socjalna), reformizm czy pojmowana w sposób socjalistyczny wolność ${ }^{40}$. W sposób wyraźny nawiązuje do socjademokracji istniejącej na zachodzie Europy, w szczególności w Niemczech, od początku XX w. W niektórych miejscach odwołuje się też do bardziej radykalnych idei oświeceniowych, typowych dla myśli francuskiej (również lat ostatnich).

W porównaniu z kierunkiem socjaldemokratycznym, deklarowanym przez SLD, inne kierunki polityczne są we współczesnej Polsce nie tylko niewykrystalizowane, ale - jak się wydaje - postępuje w nich swoista dekrystali z a cj a . Jak wspomniano, także zmieniające się nazwy partii politycznych coraz mniej nawiązują do konkretnych kierunków politycznych; coraz bardziej promują natomiast wieloideowość. Widać to szczególnie na przykładach dwóch najsilniejszych partii politycznych w Polsce.

Co stanowi curiosum, na płaszczyźnie ideologicznej, niemal 30 lat po rozpoczęciu istnienia pluralizmu politycznego i w okresie transformacji do głoszonej powszechnie idei gospodarki rynkowej, w sensie ideowym nie istnieje np. partia liberalna ${ }^{41}$. W nazwie partią taką miał być zapewne $w$ jakiejś mierze poprzednik Platformy Obywatelskiej — Kongres Liberalno-Demokratyczny. Nazwa partii miała prawdopodobnie nawiązywać do liberalizmu demokratycznego, choć obecnie również do tego kierunku myśli liberalnej nie odwołuje się w Polsce żadna znacząca partia polityczna. Następczyni Kongresu, Platforma Obywatelska, prezentuje nazwę bardzo dziwną. Semantycznie miano to kojarzy się bardziej z kierunkami socjalistycznymi niż z liberalizmem. Z kolei programowo PO - wypada dodać - nie odwołuje się zresztą do żadnego ugrupowania politycznego, także do Kongresu Liberalno-Demokratycznego ani do Unii Wolności ${ }^{42}$.

Program Platformy Obywatelskiej zakłada znacznie bardziej doraźne cele niż program ideowy. Jest zatem zbiorem postulatów dotyczących „naprawy państwa” oraz „planem rządzenia” na najbliższe lata ${ }^{43}$. Ani razu w dokumentach programowych partii, mających stanowić surogat programu ideologicznego, nie pada

40 Jest to wolność „wyboru, przekonań, nauki, sztuki, swobód obywatelskich i stylu życia oraz zrozumienie dla innych”. Autorzy programu SLD piszą: „Wolność to jednocześnie tolerancja i neutralność światopoglądowa świeckiego państwa [...] Równość, braterstwo, rozwój społeczny i postęp, a nie tylko wzrost gospodarczy”. Program deklaruje także „obronę wykluczonych, kulturę i oświatę dla wszystkich, prawo swobodnego wyboru, walkę o Europę socjalną dynamiczne i służebne państwo" (ibidem).

41 Słabość liberalizmu w Polsce odnotowało co najmniej kilku autorów. Por. np. H. Olszewski, O odchodzeniu od demokracji (Kilka uwag historyka prawa), „Państwo i Prawo” LXI, 2006, z. 8 (726), s. 12.

42 Zob. informacje zawarte na stronie internetowej partii: www.platforma.org/historia.

${ }^{43} \mathrm{Na}$ oficjalnej stronie internetowej Platformy Obywatelskiej w rubryce „program” pierwotnie znajdowały się następujące dokumenty: Zasadnicze cele naprawy państwa. III Krajowa Konwencja Platformy Obywatelskiej RP (Warszawa, 21 maja 2006); Państwo dla obywateli: plan rządzenia 2005-2009; Biała Księga z rozmów z PiS i protokoły komisji eksperckich. Obecnie witrynę rozbudowano o bardzo wiele kwestii, programu partii jednak nie ma (zob. stronę internetową partii pod adresem www.platforma.org. W rubryce dokumenty jako ,inne” można 
termin „liberalizm”, który — jako kierunek polityczny — jest kojarzony z tą właśnie partią. Dokumenty programowe PO poświęcają co prawda stosunkowo dużo miejsca zagadnien i om g o spodarczym; jest to jednak nie ideologiczne, a w ogromnej większości techniczno-kazuistyczne omówienie poszczególnych instytucji. Omawiane dokumenty wymieniają również zasadę wolności gospodarczej, ale jest to oczywiście zbyt mało, aby w sensie deklaratywno-programowym można uznać tę partię za liberalną. Jak wspomniano, o liberalizmie nie mówi expressis verbis żaden z najważniejszych dokumentów programowych partii, także w kontekście „zasad rządzenia” czy „naprawy państwa”"44.

Podobnie za liberalną można uznać partię .Nowoczesna (z umieszczoną w nazwie kropką przed początkiem wyrazu). Podobnie jak w wypadku innych partii, nazwa taka jest nie tylko niejasna, ale z powodu umieszczonej przed wyrazem kropki zupełnie niezrozumiała ${ }^{45}$. W sensie ustrojowym program .Nowoczesnej zakłada w szczególności „system premierowski”, w kontekście „spójnej i efektywnej polityki" rządzenia, przy założeniu odpowiedzialności polityków i większości parlamentarnej oraz ograniczenia roli prezydenta. Proponuje ograniczenie kadencji posłów do dwóch lat czy też stworzenie Senatu z przedstawicieli jednostek samorządu terytorialnego wraz ze skróceniem o połowę (do dwóch lat) kadencji izby drugiej ${ }^{46}$.

W ideowym sensie podstawowych kierunków nowożytnej myśli politycznej podobnie jak program Platformy Obywatelskiej przedstawia się program partii Prawo i Sprawiedliwość. Tak jak poprzednio, dziwna wydaje się już sama nazwa partii - miano Prawo i Sprawiedliwość może bowiem bardziej kojarzyć się z myślą konserwatywną niż nazwa Platforma Obywatelska z kierunkiem liberalnym, zwłaszcza w kontekście XVII-wiecznych myślicieli francuskich ${ }^{47}$. W programach PiS z 2006 i 2014 r. termin „k on s e rw aty z m” jednak w ogóle nie występował ${ }^{48}$. Jest to więc powtórzenie sytuacji Platformy Obywatelskiej, explicite nieodwołującej się do liberalizmu.

znaleźć natomiast propozycje PO dotyczące zmiany konstytucji (deklaruje się np. zmniejszenie liczby posłów do 300). Nie są to jednak zmiany istotne (ibidem).

44 Ibidem.

45 Genezy nazwy ani program, ani dostępne informacje o partii nie wyjaśniają. Formalna nazwa brzmi Nowoczesna Ryszarda Petru, jako odróżnienie od niezwiązanej z ugrupowaniem innej fundacji o podobnej nazwie.

46 Program partii pt. Nowoczesna Polska dla każdego (strona internetowa nowoczesna.org). Inne postulaty obejmują wzmocnienie roli Trybunału Konstytucyjnego i Trybunału Stanu (karanie polityków), wzmocnienie wolności gospodarczej, w tym deregulację gospodarki, ,rzetelne przedstawianie polskiej historii" itd.

47 Por. m.in. słynne zawołanie francuskich zwolenników Ludwika XVI: pro fide, rege et lege ('za wiarę, króla i prawo').

$48 \mathrm{~W}$ programie z $2014 \mathrm{r}$. kilkakrotnie pojawiło się twierdzenie, że partia razem z brytyjskimi konserwatystami doprowadziła do intensyfikacji polskiego sektora rolniczego i i zwiększenia dopłat dla polskich rolników z funduszy Unii Europejskiej. 
Podobnie jak program PO, program PiS zawiera konstrukcję „na prawy p a ń s twa". Pisał także o Polsce solidarnej, co mogło wskazywać na pierwiastki konserwatyzmu (typowe np. dla myśli niemieckiej XIX w.). Pierwiastki takie można — być może — dostrzec tym bardziej, że — jak piszą autorzy programu — Polska solidarna ma być w swej istocie ,antyliberalna”. W programie PiS brak jednak jasno określonego kierunku politycznego partii, występują natomiast zjawiska charakterystyczne bynajmniej nie dla myśli prawicowej.

Naczelną ideą, wyrażoną w programie z 2006 r., było „pańs two Nowej Umowy Społecznej"49 (pisanej czasami wielką literą). Samo pojęcie, a w zasadzie dwa ostatnie słowa, zdecydowanie typowe były nie dla prawicy, choć w zakończeniu program wyrażał idee solidaryzmu, zdecydowanie typowe dla konserwatyzmu XIX-wiecznych Niemiec ${ }^{50}$. Także niektóre inne czołowe hasła programu PiS wykazywały wtedy brzmienie lewicowe. Partia proponowała np. „pakt społeczny”, w myśl którego „ze wzrostu gospodarczego muszą korzystać wszyscy Polacy, nie tylko grupa najbogatszych" ${ }^{51}$. Tego typu idee w sposób zdecydowany kojarzą się z wkraczaniem państwa w różne sfery życia i, jak wskazywano, nie są najczęściej typowe dla myśli konserwatywnej, choć czasami w niej obecne (np. w myśli niemieckiej ${ }^{52}$ ). Niekiedy hasła takie mają jednak charakter państwa świadczącego, typowego dla myśli lewicy ${ }^{53}$. Dawniejsze naczelne hasło partii: „s prawiedliwość dla ws zy stkich" ${ }^{54}$ również nie bardzo kojarzy się z myślą prawicową; może natomiast — podświadomie nawiązywać do jakichś koncepcji sprawiedliwości wyrównawczej (równościowej), stworzonej przez Arystotelesa. Zdecydowanie nieprawicowy jest z kolei wyrażany w programach postulat ograniczenia „k o r p or a c jo n i z mu”.

Ponadto niektóre idee w programie PiS wykazują pierwiastki typowe dla myśli liberalnej. Liberalna jest już sama idea „taniego państwa”, kojarzona z jedną z najistotniejszych zasad tej partii. Tanie państwo może kojarzyć się z liberalizmem w jego zdeklarowanej, amerykańskiej postaci (Robert Nozick). Ślady takiego rozumowania widać też w programie partii, gdy mówi się o likwidacji „wielu agencji, funduszy i urzędów” 55 . Jest to oczywiście także zasada walki z biurokracją, typowa dla wielu rządów i (mniej) dla kierunków politycznych.

49 Zob. program partii Prawo i Sprawiedliwość (www.pis.org.pl).

50 W zakończeniu rozdziału IX programu PiS z 2006 r. wskazano: „Nie będziesz sam. Żaden Polak nie będzie czuł się wykluczony ani pozostawiony samemu sobie. »Bogaci mniej zamożnym, silniejsi słabszym« - na tym zasadza się nasza idea umowy społecznej. Przygotowane przez nas programy przeciwdziałania bezrobociu, biedzie i wykluczeniu, przywrócą nadzieję, chęć do życia i polepszenia własnego losu" (ibidem).

51 Ibidem.

52 Nieco radykalne wydają się jednak przy tym niektóre hasła, jak np. nie uzasadniane konkretnie w programie oddłużenie szpitali czy dożywianie dzieci w szkołach (ibidem).

53 Vide poprzedni przypis.

54 Program PiS z 2006 r.

55 Program nie zawierał w tej kwestii wielu szczegółów (zob. ibidem, rozdz. 4). 
Znacznie bardziej konkretne niż ideologiczne określone są w programie PiS zasady państwa. Ma być to państwo uczciwe, silne, sprawne, w którym istotną ideę stanowi bezpieczeństwo. Ciekawe są również propozycje partii w zakresie polityki międzynarodowej. Wszystkie wskazane określenia mogą odnosić się w pewien sposób do politycznej koncepcji „racji stanu”, który to termin pojawia się zresztą w programie ${ }^{56}$. Tyle, że pojęcie to od co najmniej wieku nie jest typowe dla konkretnej idei politycznej ani — tym bardziej — dla jednego kierunku politycznego.

Pozostałe obecne na polskiej scenie politycznej partie, mające reprezentację parlamentarną, najczęściej zaliczane są do populistycznych. Cechą systemu politycznego Polski w tym aspekcie zdaje się postępująca radyka li za cja lewicy i prawicy. Najbardziej określone (w postaci kierunku politycznego) wśród takich partii były partie nacjonalistyczne, jak swego czasu Liga Polskich Rodzin. Partia ta w sposób wyraźny nawiązywała do myśli narodowej demokracji sprzed 1939 r., deklarując „ciągłość tradycji i kultury narodowej”, zasady państwa określone w takich instytucjach, jak ,człowiek, rodzina, społeczność, gmina”. Inne zasady charakterystyczne dla dawnej narodowej demokracji to upowszechnienie własności wśród polskich obywateli czy też „nacjonalizacja” polskiego „majątku narodowego sprzedanego z naruszeniem prawa po cenach kupna", dążenie do „samowystarczalności żywnościowej” kraju czy do zrównoważenia bilansu handlowego z państwami obcymi. Typowo przedwojenne są np. postulaty „zapewnienia osobnego mieszkania każdej rodzinie, a docelowo zapewnienie samowystarczalności mieszkaniowej każdej gminy”. Do postulatów wyrażanych przez narodową demokrację przed 1939 r. w programie partii znajdują się również współczesne implikacje takiego podejścia. Należą do nich m.in. postulaty ,antyglobalizacji i antyunifikacji narodowej”, a także wyrażony expressis verbis sprzeciw wobec wstąpienia Polski do Wspólnot Europejskich ${ }^{57}$. Jak była już mowa, program Ligi Polskich Rodzin pozwala umieścić tę partię jako najbardziej, poza SLD, określone programowo polskie ugrupowanie parlamentarne III Rzeczypospolitej. Obecni „narodowcy”, by użyć określenia tego właśnie ruchu o sobie samym, weszli do Sejmu w ramach Stowarzyszenia Kukiz '15.

Znacznie mniejszą krystalizację programu wykazywała druga z partii politycznych, mających dawniej reprezentację parlamentarną, a uznawanych często za populistyczne, jaką była Samoobrona Rzeczypospolitej Polskiej. Warta wskazania partia stanowiła fenomen w polskim systemie politycznym. Jak już stwierdzono, w sensie formalnym Samoobrona była zarówno partią polityczną, jak i związkiem zawodowym, co do pewnego stopnia było zjawiskiem typowym dla systemu politycznego III Rzeczypospolitej. Według ogłoszonego dawniej programu Samoobrona

\footnotetext{
56 Por. ibidem, rozdz. 8.

57 Wszystkie zaznaczone fragmenty cytowane według programu LPR (www.lpr.pl).
} 
RP ,czerpie swój program z nauki Kościoła”; w programie nie ma jednak odniesień do katolickiej nauki społecznej ani konkretnych jej zasad.

Expressis verbis program Samoobrony określał się jako „koncepcja trzeciej drogi”, głosząc poszukiwanie ,innych niż powrót do kapitalizmu” rozwiązań społecznych i politycznych. Jak się wydaje, poszukiwania takie szły znacznie bardziej w kierunku socjalizmu niż kapitalizmu. Partia proponuje np. wprowadzenie znacznych elementów planowości w gospodarce, występując przeciwko „redukcjonistycznej”, jak określa to program, „metodzie dzielenia gospodarki na »kawałki«" ${ }^{58}$. Według autorów programu, system władzy w Polsce powinien ewoluować w kierunku „demokracji materialnej” (rozumianej w kontekście finansowym), tzn. takiej, „w której jej społeczne i polityczne dobrodziejstwa będą odczuwane bezpośrednio przez wszystkich obywateli bez różnicy sytuacji ich społecznego statusu, a tylko jako należne im korzyści po spełnieniu wszystkich obywatelskich obowiązków". Zaprezentowane idee wyrażały klasyczny p o p u li z m, obiecując spełnianie oczekiwań (mniej niż potrzeb) jak największej liczby ludzi i operując przy tym za każdym razem stereotypem ludzi prostych ${ }^{59}$ jako beneficjentów takiego programu.

W sensie realizacji podobnych idei, program Samoobrony RP wykazywał silne elementy socjalne w znaczeniu, o którym była już mowa, tj. w kontekście silnego państwa opiekuńczego. Na tym tle program prezentował wiele pomysłów, postulując np., by opracowana w przyszłości konstytucja deklarowała ,prawo do zaspokajania potrzeb mieszkaniowych".

Wydaje się, że wraz z formowaniem wielu postulatów ,socjalnych”, program Samoobrony proponował także pewne rozwiązania autorytarne. Takim rozwiązaniem ustrojowym była m.in. propozycja wprowadzenia w Polsce dekretów prezydenta z mocą ustawy (co prawda w ,sytuacjach nadzwyczajnych") ${ }^{60}$, przy jednoczesnej likwidacji Senatu $\mathrm{RP}^{61}$. Wszystkie opisane postulaty ustrojowe i polityczne każą określić zjawisko partii Samoobrona jako nieskrystalizowany z punktu widzenia nowożytnych kierunków myśli politycznej.

Na zakończenie warto wspomnieć o próbach tworzenia w Polsce po $1989 \mathrm{r}$. partii władzy, typowej dla autorytaryzmu. Pierwotnie była nią mało dziś znana Partia „Victoria” (grupująca, jak stwierdzał program, „wyborców Lecha Wałęsy”).

$58, »$ Redukcjonistyczna« metoda dzielenia gospodarki na »kawałki« i krótkoterminowe, cząstkowe rozwiązywanie problemów są widoczne obecnie na przykładzie górnictwa, rolnictwa, poszczególnych branż przemysłowych itd. Wynika to wszystko z anglo-germańskiej mentalności opartej na protestanckim dogmacie predestynacji, czyli boskim przeznaczeniu" - piszą autorzy programu Samoobrony (por. www.samoobrona.pl).

59 Zob. np. definicję populizmu według pracy: V. Khoros, Populism. Its Past, Present and Future, Moscow 1980.

60 Zob. projekt konstytucji autorstwa Samoobrony RP (www.samoobrona.pl). Pojęcia „sytuacji nadzwyczajnych" program nie definiował. Warto dodać, że projekt konstytucji, autorstwa tej partii jest prawie identyczny z obowiązującą obecnie konstytucją RP.

${ }^{61}$ Ibidem. 
Pierwszy prezydent III Rzeczypospolitej wysunął także projekt restytucji Bezpartyjnego Bloku Wspierania Reform, nawiązującego (również skrótem) do przedwojennego Bezpartyjnego Bloku Współpracy z Rządem. Przed wojną — jak wiadomo - ów specyficznie polski polityczny twór w swym założeniu miał być bezpartyjny, tj. nie reprezentować żadnego kierunku politycznego, i prorządowy, aczkolwiek reprezentujący poparcie tylko jednej siły politycznej (wtedy tzw. sanacji). Takie programowe ujęcie partii politycznej, typowe dla autorytaryzmu, promowało również wieloideowość i niedookreślenie kierunku politycznego, istotnego też z punktu widzenia ustroju państwa ${ }^{62}$.

We współczesnej Polsce rozwiązania takie przyjmowane są co pewien czas. Widać w nich m.in. swoiste dryfowanie partii rządzącej (AWS, SLD, obecnie być może także PiS) w kierunku ugrupowania mało politycznie sprecyzowanego, uosabiającego „partię władzy”. Zjawisko takie — jak wiadomo — jest również typową cechą myśli autorytarnej.

Jak widać, system polityczny współczesnej Polski daleki jest od wykrystalizowania. Jak była mowa, krystalizacja kierunków politycznych nie tylko nie następuje, ale system wykazuje wręcz cechy uwsteczniania. W sensie programowym do pewnego stopnia pozostaje wykrystalizowana jedynie pozostająca poza parlamentem socjaldemokracja, zdominowana przez jedną partię polityczną. Dodatkowo oficjalnie nie istnieją w Polsce odgrywające polityczną rolę partia liberalna i partia konserwatywna; w sensie programowym oba kierunki nie są reprezentowane w parlamencie.

Analiza programów partii politycznych prowadzi czasem do zaskakujących wniosków; pokazuje mianowicie, że w wielu wypadkach nie prezentują one nie tylko spójnej, ale nawet jasno określonej ideologii, dokonując $\mathrm{w}$ wielu wypadkach wymieszania idei typowych dla różnych kierunków politycznych ${ }^{63}$. Popularna z punktu widzenia zabiegania o wyborców wydaje się zatem wieloideowość. Prawdopodobnie dlatego najważniejsze na polskiej scenie politycznej partie polityczne unikają w swych programach sprecyzowania kierunku politycznego. Powoduje to jednak ich polityczną deprawację. Świadectwem takiego zjawiska jest występujące w ostatnich latach w Polsce odrodzenie i intensyfikacja populizmu, powodujące wypieranie kierunków politycznych przez ich surogaty, zawierane w programach partii politycznych ${ }^{64}$.

62 Partia tego typu zawsze była ugrupowaniem uprzywilejowanym, co skutkowało faktycznym lub prawnym upośledzeniem innych partii, zwłaszcza opozycyjnych wobec takiego ugrupowania rządowego.

63 Jak była mowa, uznawana za najważniejszą partię prawicową partia polityczna współczesnej Polski proponuje np. teorię nowoczesnej umowy społecznej, typową dla klasycznej europejskiej lewicy od czasów oświecenia.

${ }^{64} \mathrm{Na}$ takiej właśnie zasadzie Platforma Obywatelska prezentuje ułamki programu liberalnego, Prawo i Sprawiedliwość - skrawki konserwatyzmu, Samoobrona RP - elementy myśli lewicowej, a Liga Polskich Rodzin deklarowała przywiązanie do społecznej nauki Kościoła. W sposób 
Populistyczne tendencje widać także $\mathrm{w}$ istniejących od kilku lat nazwach partii politycznych, które wykształciły się z określeń nieco lepiej oddających polityczne umiejscowienie konkretnych partii. Sytuacja taka musi powodować fluktuacje i brak stabilności systemu politycznego, a w konsekwencji jest jedną z przyczyn niezbudowania nowoczesnego systemu politycznego państwa przez prawie 30 ostatnich lat.

Trudno więc mówić o wykształconej w takim systemie stabilnej formie państwa prawnego czy nawet szerzej - społeczeństwa obywatelskiego ${ }^{65}$. Warto zauważyć, że z drugiej jednak strony niestabilność systemu partyjnego świadczy o niechęci do zbudowania jakiejś formy autorytaryzmu.

O ile jednak partie polityczne dalekie są od krystalizacji, polski system konstytucyjny należy uznać za znacznie bardziej dojrzały. Wykazuje on przede wszystkim bardzo ciekawy katalog wartości, typowych dla podstawowych kierunków nowożytnej myśli politycznej.

Mimo pojawiających się pomysłów wzmocnienia roli prezydenta czy nawet wyposażenia głowy państwa w prawo „skrócenia” kadencji Sejmu, mało prawdopodobne jest zbudowanie w Polsce systemu autorytarnego ${ }^{66}$. Zaskakujące są w tym przypadku paralele z rzeczywistością II Rzeczypospolitej bądź też programem sanacji ${ }^{67}$. Współcześnie zwraca się oczywiście uwagę na „kontestowanie

oczywisty wskazane partie polityczne nie reprezentują jednak takich kierunków politycznych albo są jedynie ich karykaturą.

65 O społeczeństwie obywatelskim w tym kontekście por. np. H. Olszewski, op. cit., s. 13.

66 Jak wykazano, ciekawe jest, że postulaty autorytarne zgłaszają w tym przypadku różne partie i niesprecyzowane ruchy polityczne, których programy częstokroć nie są dojrzałe nie tylko z punktu widzenia państwa współczesnego. Niezależnie od tego budowie państwa autorytarnego nie sprzyja rozczłonkowanie sceny politycznej w Polsce i częste zmiany systemu partyjnego. Warto też dodać, że aczkolwiek system prezydencki nie wydaje się optymalnym rozwiązaniem dla polskiego modelu ustrojowego, w Stanach Zjednoczonych czy Francji (w ostatniej — rzecz jasna — z pewnymi modyfikacjami) nie ogranicza systemu państwa prawnego (z prac ostatnich por. M. Wąsowicz, Prawo i obywatel. Rzecz o historyczno-prawnych korzeniach europejskiego standardu ustrojowego, Warszawa 2015, s. 126-127).

${ }^{67}$ Chodzi np. o techniczną sprawność rządzenia czy nową umowę społeczną, obecną w dawnym programie PiS i tezach Piłsudskiego (patrz wcześniej). Współczesną tak szczegółową inspirację programem marszałka należy zdecydowanie wykluczyć. Warto też odnotować, że choć obecnie program uzdrowienia (także moralnego) państwa należy do kanonu programów partii politycznych, termin „sanacja” w takich programach, a w szczególności w programie partii Prawo i Sprawiedliwość, nie występuje. Por. także M. Czaja, IV Rzeczpospolita jako próba sanacji państwa, „Pisma Humanistyczne” XI, 2013, s. 57-73; K. Patkowski, B. Pająk-Patkowska, Weggierska droga do i od demokracji, „Przegląd Politologiczny” 2, 2014, s. 21-35. Ostatni artykuł powstał przed zwycięskimi dla PiS wyborami parlamentarnymi i nie powinien być łączony z bieżącą walką polityczną w Polsce (odpowiednio pozytywny i negatywny przykład ewolucji węgierskiego systemu politycznego przywołuje po wyborach 2015 r. rząd i opozycja). 
roli sądów z Trybunałem Konstytucyjnym na czele"68. Potrzebą chwili jest natomiast dookreślanie państwa prawnego i kategorii dobrych praktyk prawnych, w tym administracyjnych, czy konwenansów konstytucyjnych i administracyjnych, typowych właśnie dla rozwiniętego państwa współczesnego. Wskazane zagadnienia muszą odgrywać znaczącą rolę w mocno ułomnym polskim systemie władzy publicznej, którą to i związane z nią rozważania, zarysowane w prezentowanym tekście, autor chciałby przedstawić w odrębnej formie w przyszłości.

\section{Bibliografia (wybrana)}

Bosiacki A., Ewolucja myśli polityczno-państwowej Józefa Pitsudskiego oraz jej wpływ na myśl spoleczna i dokonania Drugiej Rzeczypospolitej, „Studia nad Autorytaryzmem i Totalitaryzmem” 37, 2015, nr 2, „Acta Universitatis Wratislaviensis” 3687.

Bosiacki A., Kierunki nowożytnej myśli politycznej w programach polskich ruchów politycznych lat 1989-2006, [w]: Ideowość w polityce, red. M. Szyszkowska, Warszawa 2007.

Czaja M., IV Rzeczpospolita jako próba sanacji państwa, „Pisma Humanistyczne” XI, 2013.

Garlicki A., Józef Pitsudski 1867-1935, Kraków 2008.

Godlewski T., Identyfikacje ideologiczne a preferencje wyborcze społeczeństwa polskiego, „Historia i Polityka" 2016, nr 15 (22).

Izdebski H., Doktryny polityczno-prawne. Fundamenty wspótczesnych państw, wyd. 3, Warszawa 2015.

Kaczyński J., Porozumienie przeciw monowładzy. Z dziejów PC, Warszawa 2016.

Kulesza W.T., Koncepcje ideowo-polityczne obozu rządzacego w Polsce w latach 1926-1935, Wrocław 1985.

Kurski J., Semka P., Lewy Czerwcowy, Warszawa 1992.

Lewandowska-Malec I., Demokracje polskie. Tradycje — współczesność - oczekiwania, Kraków 2013.

Maciszewski W., Bezpieczne zwiazki, „Gazeta Wyborcza”, 27.08.2005.

Mohl R. von, Die Polizeiwissenschaft nach den Grundlagen des Rechtsstaates, t. I, Tübingen 1832, t. II: 1834, t. III: 1866.

Mohl R. von, Encyklopedia umiejętności politycznych, przeł. A. Białecki, red. A. Bosiacki, wyd. II, Warszawa 2003.

Mohl R. von, System parlamentarny, [w:] B. Sobolewska, M. Sobolewski, Myśl polityczna XIX i XX wieku. Liberalizm, Warszawa 1978.

Olszewski H., O odchodzeniu od demokracji (Kilka uwag historyka prawa), „Państwo i Prawo” LXI, 2006, z. 8.

Scriptor (Erazm Piltz), Nasze stronnictwa skrajne, Kraków 1903.

Skwarczyński A., Od demokratyzmu do autorytaryzmu, Warszawa 1998.

Patkowski K., Pająk-Patkowska B., Węgierska droga do i od demokracji, „Przegląd Politologiczny” 2, 2014.

Piasecki A., Tezy konstytucyjne Marszałka Piłsudskiego. Referat wygłoszony w dniu 28 lutego 1931 r. u Marszałka Senatu Władysława Raczkiewicza. Drukowane jako rękopis [broszura], Warszawa 1931.

68 Por. np. H. Olszewski, op. cit., s. 14. Dodatkowo, tekst został opublikowany w 2006 r., niezależnie od bieżących bardzo ostrych sporów politycznych, spowodowanych narastaniem wskazywanego przez niektóre siły polityczne tzw. kryzysu konstytucyjnego. 
PiS usunęto z sieci projekt swojej konstytucji. Co zawiera ten dokument, „Gazeta Prawna”, 20.10.2015, http://www.gazetaprawna.pl/artykuly/900647,projekt-konstytucji-pis-wyboryparlamentarne-2015.html.

Pismo do marszałka Sejmu, zawiadamiajace o nieprzyjęciu wyboru na [urzad] Prezydenta Rzeczypospolitej, [w:] J. Piłsudski, Pisma zbiorowe, t. 9, Warszawa 1938.

Podgajna E., Obchody 25-lecia Solidarności, „Gazeta Wyborcza”, 28.08.2005.

Staniszkis J., Postkomunizm: próba opisu, Gdańsk 2001.

Szewczak W., Dyskurs publiczny jako substytut reprezentacji politycznej - wymiar parainstytucjonalny wspótczesnej demokracji, http://www.academia.edu/5531857/Dyskurs_publiczny_jako_ substytut_reprezentacji_politycznej_wymiar_parainstytucjonalny_wsp $\% \mathrm{C} 3 \% \mathrm{~B} 3 \% \mathrm{C} 5 \% 82 \mathrm{cze}-$ snej_demokracji.

\section{BETWEEN THE RULE OF LAW AND AUTHORITARIANISM. POLISH CONSIDERATIONS ON SEEKING THE OPTIMAL STATE SYSTEM AFTER REGAINING INDEPENDENCE IN THE THIRD REPUBLIC}

\section{Summary}

The article presents an analysis of selected considerations of Polish political discussions about the shortcomings of the parliamentary system and their antidote in the form of an authoritarian system. The point of departure is an analysis of the idea of a legal state (Rechtsstaat), well known in Congress Kingdom even before Poland regained its independence in 1918. It is also worthwhile to research the attempt of the integration the head of state into the parliamentary system, which was successfully applied between 1918 and 1922 when the Head of State institution was personalized by Józef Pilsudski. The analysis of the authoritarian thinking of Piłsudskis movement between 1926-1939 did not turn out as it had been declared, the sanation of state, and ideologically — also experienced - numerous social failures. Piłsudski's legacy is present to some extent in contemporary Poland, with few exceptions (e.g. the concept of the common good), but one cannot speak of the legacy of authoritarianism. The idea of authoritarianism, however, remains less or more attractive as the solution to the social pains of the Third Republic. As between 1918-1922 in Poland, it has now been possible to incorporate the president's powers into the parliamentary system, where the head of state is not a purely decorative body (to a certain extent as a moderator of the empire). The list of constitutional values is also important. The underserved party system (before the war and now) is undoubtedly a negative political tendency, although such a system is not a developed state legal system. Paradoxically, however, it fosters anti-authoritarian tendencies.

Keywords: parliamentarism, parliamentary-cabinet system, authoritarianism, Second Republic of Poland, Third Republic of Poland, political system of contemporary Poland, post-communism.

Adam Bosiacki

abosiacki@wpia.uw.edu.pl 